\title{
Profil Penalaran Moral Peserta Didik Kelas VIII di SMP Negeri 2 Ciledug, Kab. Cirebon
}

\author{
Palasara Brahmani Laras \\ Program Studi Bimbingan dan Konseling, Fakultas Keguruan dan Ilmu Pendidikan, \\ Universitas Mercu Buana Yogyakarta \\ palasara@mercubuana-yogya.ac.id
}

\begin{abstract}
Abstrak
Penalaran moral sebagai kemampuan kognitif individu dalam menimbang atau merespon suatu keputusan untuk menentukan sebuah tindakan. Penalaran moral menjadi prediktor perilaku kenakalan remaja, semakin rendah penalaran moral remaja, semakin tinggi perilaku kenakalannya. Menurut Kohlberg mengemukakan meskipun banyak faktor yang menimbulkan kenakalan remaja, tetapi tingkatan penalaran moral yang tinggi sekurang-kurangnya dapat berfungsi sebagai penghambat perilaku kenakalan. Oleh karena itu, untuk menemukan perilaku moral yang sebenarnya dapat ditelusuri memalui penalaran moralnya. Dalam rangka mengembangkan penalaran moral peserta didik, diperlukan strategi bimbingan dan konseling yang dirancang secara komprehensif, memenuhi kebutuhan siswa dan terandalkan melalui proses pengujian ilmiah. Agar peserta didik dapat meningkatkan penalaran moralnya secara efektif maka perlu dicari tahu terlebih dahulu gambaran atau profil dari tahapan penalaran moral peserta didik untuk selanjutnya disusun rancangan kegiatan bimbingan yang terencana, terorganisasi dan terkoordinasi selama periode waktu tertentu di sekolah.
\end{abstract}

Kata Kunci: Penalaran Moral; Profil Penalaran Moral; Peserta Didik.

\begin{abstract}
Moral reasoning as the cognitive ability of individuals in weighing or responding to a decision to determine an action. Moral reasoning is a predictor of juvenile delinquency behavior, the lower morale of adolescents, the higher their delinquency behavior. According to Kohlberg suggested several factors that cause juvenile delinquency, but raising high morale at least can be used as a barrier to delinquency behavior. Therefore, to find the actual moral behavior can be traced through penalties, the moral. In the framework of developing student morale penalties, guidance and counseling strategies are specifically designed, meet student needs and are relied upon through a scientific testing process. In order for students to be able to increase their moral penalties, it is necessary to find out in advance or the profile of the students' moral raising to further develop a planned, organized and coordinated activity plan for a certain period of time at school.
\end{abstract}

Keywords: Moral Reasoning; Moral Reasoning Profile; Student. 


\section{PENDAHULUAN}

Berbagai situasi dan persoalan yang mengandung dilema moral kerap sekali terjadi dan dialami oleh manusia dalam menjalani kehidupannya. Situasi moral tersebut merupakan sebuah situasi dan persoalan yang menuntut individu untuk dapat mempertimbangkan berbagai hipotesis nilai-nilai yang benar dan salah sebagai pertimbangan dalam memutuskan sesuatu tindakannya (Slavin, 2011, hlm. 71). Individu dituntut untuk mampu memberikan respon pertimbangan secara tepat dan benar agar keputusan atau perilakunya sejalan dengan aturan, norma, adat istiadat, undang-undang dan hukum yang ada dalam masyarakat. Cara individu dalam membuat suatu keputusan tentang tindakan dalam menghadapi dilema moral banyak dipengaruhi oleh salah satunya adalah penalaran moral (Bartels, dkk, 2015).

Penalaran atau pertimbangan moral muncul ketika individu dihadapkan pada sebuah peristiwa, keadaaan, realitas, kenyataan, masalah dan kebutuhan yang berhubungan dengan dilema moral (Abdolmohammadi, \& Baker, 2006). Penalaran moral berperan penting dan berpengaruh secara signifikan dalam proses pengambilan keputusan untuk menentukan benar, salah dan tindakan terbaik yang harus dilakukan dalam situasi tertentu yang mengandung dilema moral (Sadler \& Zeidler, 2005; Flaherty \& Gleeson, 2014). Selain itu, penalaran moral sebagai cara individu berpikir dan sebagai dasar untuk berperilaku etis, yaitu perilaku yang sesuai dengan norma-norma sosial, agama yang secara umum berhubungan dengan tindakan-tindakan yang bermanfaat seperti menghargai orang lain, berempati dan tolong-menolong (Rose, 2012).

Kemampuan penalaran moral yang baik akan membuat individu mampu menimbang segala sesuatunya yang berkaitan dengan moral, mampu menimbang mana perbuatan yang baik dan mana yang buruk sesuai dengan nilai-nilai norma yang dianutnya secara pribadi dan sesuai dengan yang ada di lingkungan masyarakatnya (Joanne, 2014). Senada dengan hal itu, Gordon \& Heincke (2013) menyatakan bahwa penalaran moral sangat penting dimiliki, sebagai salah satu kemampuan kognitif yang berguna bagi kehidupan terkait dalam menghadapi situasi yang mengandung dilema moral. Serta individu dengan penalaran moral yang tinggi banyak dibutuhkan di dunia kerja dan mudah berempati dengan lebih baik (Lewis \& Young, 2000).

Penalaran moral dapat menumbuhkan kecerdasan moral yang sangat penting dikembangkan agar anak mempunyai suara hati dan bisa membedakan mana yang benar dan mana yang salah, sehingga anak dapat menangkis pengaruh buruk dari luar (Borba, 2008, hlm. 6). Selain itu penalaran moral penting ditanamkan pada siswa di sekolah, selain kecerdasan akademik, karena dapat berguna dalam kehidupan pribadi maupun sosialnya (Flaherty \& Gleeson, 2014). Penelitian Abdolmohammadi \& Sultan (2002); Ponemon \& College (1992) menemukan bahwa individu yang memiliki tingkat penalaran moral tinggi akan berperilaku berbeda ketika dihadapkan dengan situasi yang menyebabkan dilema yaitu individu dapat memutuskan tindakan yang harus dilakukan secara bertanggungjawab. Hal ini senada dengan penelitian Candee \& Kohlberg, 1987 (dalam Horstink. 2012) menunjukkan bahwa orang dengan tingkat penalaran moral yang lebih tinggi lebih konsisten dalam tindakannya ketika menghadapi situasi yang melibatkan dilema moral. 
Beberapa penelitian mengkaitkan penalaran moral dengan perilaku disiplin. Ilham (2012) menguji hubungan antara penalaran moral dengan perilaku disiplin peserta didik di SMK 1 Sragen, hasilnya ditemukan terdapat hubungan yang sangat signifikan antara penalaran moral dengan kedisiplinan siswa. Kemudian penelitian Purwanti \& Muhari (2013) menemukan bahwa ada hubungan yang negatif dan signifikan antara tingkat penalaran moral pada remaja dengan perilaku seks pranikah. Semakin tinggi tingkat penalaran moral pada remaja semakin rendah perilaku seks pranikahnya, dan begitu juga sebaliknya. Semakin rendah tingkat penalaran moral pada remaja, semakin tinggi perilaku seks pranikahnya.

Basyirudin (2010) dalam penelitiannya menemukan ada hubungan yang negaif dan signifikan antara penalaran moral dengan perilaku bullying. Serta pada remaja yang suka membully temannya cenderung memiliki penalaran moral yang rendah (Perren, 2012). Menurut Uddin \& Gillet (2002) dan Xu \& Ziegenfuss (2008) dalam penelitiannya menemukan bahwa individu yang memiliki penalaran moral tinggi cenderung berperilaku etis dan sebaliknya. Selain itu, penelitian Abdolmohammadi \& Baker (2006) menemukan bahwa penalaran moral mempunyai hubungan yang positif dengan aktualisasi diri dan idealisme. Hasil penelitian tersebut, menggambarkan bahwa penalaran moral penting dimiliki individu baik anak-anak, remaja dan orang dewasa untuk keberlangsungan hidup pada beragam aspek kehidupan. Kohlberg (dalam Santrock, 2003) mengemukakan bahwa perkembangan moral pada anak, remaja dan orang dewasa merupakan hal yang penting, tidak hanya untuk pencapaiannya, tetapi juga untuk kesuksesannya dalam semua bidang. Lebih lanjut Kohlberg menyatakan bahwa perilaku yang baik yang ditunjukkan oleh anak dan remaja terutama disebabkan oleh penalaran moralnya yang tinggi, sehingga kesadaran moralnya baik. Fakta empirk menunjukkan bahwa saat perkembangan moral diutamakan pada masa anak-anak dan remaja, maka mereka akan cenderung menjadi (1) percaya diri, (2) kooperatif, (3) mengetahui cara bersikap dengan benar disituasi yang berbeda-beda, (4) dan pada kehidupan mereka selanjutnya untuk mempertahankan hubungan yang sehat dan seimbang, (5) dan mampu berempati kepada dengan orang lain (Astuti, 2014).

Permasalahan yang kerap muncul hampir setiap hari diberbagai media masa khususnya di Indonesia, banyak menayangkan peristiwa perilaku kriminal dan pelanggaran nilai-nilai moral yang menggambarkan rendahnya penalaran moral dengan penurunan kualitas moral dikalangan masyarakat, baik dilakukan oleh anak-anak, para pelajar sekolah, remaja, orang dewasa hingga orang tua, dari yang bersifat ringan sampai berat. Bernas 1997 (dalam Muryono. 2009, hlm. 66) mengungkapkan bahwa penurunan kualitas moral yang tergolong ringan seperti sikap kurang menghargai seseorang anak kepada orang yang lebih tua, anak-anak sekarang sulit diatur, tidak patuh, suka membantah, suka mengkritik dengan cara-cara yang tidak sesuai dengan nilai-nilai moral, bahkan ada anak-anak yang berani mengancam orangtuanya ataupun gurunya. Penurunan kualitas moral yang termasuk berat dan memprihatinkan seperti hubungan seksual pranikah, pergaulan bebas, penyalahgunaan obat terlarang, tawuran antar pelajar, aborsi, perselingkuhan, pemerkosaan, korupsi, 
pembunuhan serta tindakan-tindakan yang meresahkan masyarakat termasuk dalam kategori tindakan kriminal.

Hurlock (2011, hlm. 226) berpendapat bahwa pelanggaran-pelanggaran yang dilakukan khususnya peserta didik di sekolah maupun individu di masyarakat menunjukkan rendahnya pemahaman akan nilai-nilai moral dalam kehidupan bersama. Untuk itu, penanaman nilai-nilai moral sangat dibutuhkan dalam mengoptimalkan perkembangan penalaran moral agar anak secara mandiri, mampu memilah mana perbuatan yang positif dan mana yang negatif (Ibung, 2009, hlm. 9). Penalaran moral menjadi prediktor perilaku kenakalan remaja, semakin rendah penalaran moral remaja, semakin tinggi perilaku kenakalannya (Beerthuizen., Brugman \& Basinger, 2013). Hal ini sesuai dengan asumsi yang dikemukakan oleh Kohlberg (dalam Duska dan Whelan, 1982, hlm. 111) mengemukakan meskipun banyak faktor yang menimbulkan kenakalan remaja (delinquency), tetapi tingkatan penalaran moral yang tinggi sekurang-kurangnya berfungsi sebagai penghambat perilaku delinqueant. Oleh karena itu, untuk menemukan perilaku moral yang sebenarnya dapat ditelusuri memalui penalaran moralnya. Artinya pengukuran moral yang benar tidak sekedar mengamati perilaku moral yang tampak, tetapi harus melihat pada penalaran moral yang mendasari keputusan perilaku moral.

Masa remaja merupakan suatu periode penting dalam perkembangan moral, khususnya ketika remaja beralih dari lingkungan yang relatif homogen ke lingkungan yang lebih heterogen. Di lingkungan yang heterogen individu dihadapkan pada berbagai kontradiksi antara konsep-konsep moral yang telah diterima dan dialami di luar keluarganya dan lingkungan rumahnya. Dititik ini remaja mulai mengenali serangkaian keyakinannya sekaligus menyadari bahwa keyakinan mereka itu hanyalah salah satu di antara berbagai keyakinan orang-orang lain. Ditilik dari segi perkembangan kognitifnya para remaja telah mencapai tahap oprasional formal, yaitu remaja mampu mempertimbangkan semua kemungkinan untuk menyelesaikan suatu masalah dan mampu mempertanggungjawabkannya berdasarkan suatu hipotesis atau proposisi. Dapat dikatakan bahwa remaja sudah dapat memandang masalahnya dari berbagai sudut pandang dan menyelesaikannya dengan mengambil banyak faktor sebagai dasar pertimbangan, bernalar secara lebih abstrak, idealis dan logis.

Penalaran moral berkembang dari gerakan penalaran moral heteronom ke pelanaran moral otonom. Ditegaskan oleh Piaget (Duska dan Whelan, 1982, hlm. 31) bahwa tahap perkembangan moral otonom harus dicapai selama masa remaja. Individu dengan penalaran moral otonom ditandai dengan telah dapat menempatkan diri pada posisi orang lain atau alih peran serta mampu mampu melihat tindakan dari perspektif lain yang berbeda dengan perspektifnya sendiri, sehingga remaja akan mengadakan pertimbangan atas dasar tanggungjawab subjektif. Berbeda dengan tahap penalaran moral heteronom yang menilai kebenaran atau kebaikan suatu tingkah laku dengan melihat konsekuensi dari tingkah laku tersebut, bukan dari intensi pelaku. Sementara peserta didik dalam kategori tahapan moral semi otonom (sedang) belum sepenuhnya mampu dalam menempatkan diri pada posisi orang 
lain, belum sepenuhnya mempertimbangkan berbagai alasan dalam mengambil keputusan moral, belum sepenuhnya menyadari aturan dibuat orang lain dan bisa disesuaikan.

Penalaran moral penting untuk dikembangkan pada siswa selain kecerdasan akademik karena dapat memberikan keuntungan bagi proses pendidikan siswa dan kualitas kehidupannya. Penalaran moral merupakan kemampuan kognitif yang dapat dikembangkan yang berguna dalam menimbang segala sesuatunya yang berkaitan dengan moral, mampu menimbang mana perbuatan yang baik dan mana yang buruk sesuai dengan nilai-nilai norma yang dianutnya secara pribadi maupun di lingkungan masyarakat. Wilson (Cheppy, 1988) moral tidak hanya terbatas pada kawasan interpersonal di mana permasalahan moral yang umum senantiasa berkaitan dengan personal (kepercayaan moral personal yang tidak mencangkup secara langsung perhatian terhadap kepentingan orang lain). Ditilik dari dimensi moral itu sendiri terbagi menjadi dua yaitu dimensi Intrapersonal (nilai-nilai dasar dan penghayatan mengenai diri) ranah pribadi dan dimensi interpersonal (fokus mengenai hal-hal yang sebaiknya dilakukan ketika berinteraksi dengan orang lain) sebagai ranah sosial (Santrock, 2007, hlm 301; Gibbs, 2003; Walker \& Pitts, 1998). Untuk itu agar peserta didik dapat meningkatkan penalaran moralnya secara efektif maka perlu dicari tahu gambaran tahapan penalaran moral untuk selanjutnya disusun rancangan kegiatan bimbingan khususnya pada layanan bimbingan dan konseling yang terencana, terorganisasi dan terkoordinasi selama periode waktu tertentu di sekolah.

\section{METODE PENELITIAN}

\section{Pendekatan, Metode dan Desain Penelitian}

Penelitian ini menggunakan pendekatan kuantitatif. Pemilihan pendekatan kuantitatif digunakan untuk memaparkan profil penalaran moral siswa dan mengetahui efektivitas bimbingan pribadi dalam mengembangkan penalaran moral siswa. Metode penelitian yang digunakan adalah penelitian quasi-experiment. Penelitian mengenai bimbingan pribadi untuk mengembangkan penalaran moral dilakukan dalam pembelajaran sehari-hari di kelas. Untuk itu, metode yang cocok pada penelitian ini adalah metode penelitian quasi-experiment dengan desain nonequivalent kontrol groups design (desain kelompok kontrol nonekuivalen), sebuah kelompok treatment dan sebuah kelompok pembanding (kontrol) diperbandingkan dengan menggunakan ukuran-ukuran pra-uji (pre-test) dan pasca uji (post test) (Creswell, 2010, hlm. 242).

\section{Populasi dan Sampel Penelitian}

Penelitian tentang bimbingan pribadi untuk mengembangkan penalaran moral akan dilaksanakan di SMPN 2 Ciledug Kec. Ciledug, Kab. Cirebon. Provinsi Jawa Barat. Populasi dalam penelitian ini adalah seluruh peserta didik kelas VIII SMPN 2 Ciledug Kab. Cirebon Tahun Ajaran 2016/2017 terdiri dari 7 kelas yang berjumlah 230 peserta didik. Teknik pengambilan sampel menggunakan teknik purposive sampling. Pada penelitian ini yang menjadi pertimbangan dalam pemilihan sampel adalah remaja (peserta didik) atau kelompok kelas yang berada pada tahapan penalaran moral semi otonom (sedang). 


\section{Pengembangan Instrumen}

Instrumen penalaran yang digunakan dalam penelitian ini berupa kuesioner (angket) berbentuk cerita. Masing-masing cerita memiliki tiga pilihan jawaban, setiap jawaban merupakan gambaran dari penalaran moral peserta didik. Instrumen ini merupakan adaptasi dari instrumen penalaran moral Jean Piaget. Namun dalam pengembangannya, peneliti menyesuaikan cerita dilema moral dengan kebutuhan dan karakteristik peserta didik yang peneliti teliti. Pada instrumen penalaran moral Piaget menyajikan cerita yang berisi tentang dilema-dilema moral. Cerita dilema tersebut berisi sejumlah cerita moral yang berhubungan dengan aspek kepatuhan (kesadaran akan peraturan dan pelaksanaan peraturan) melalui cerita kesembronoan, aspek kebenaran (pertimbangan benar dan salah) melalui cerita persoalan mencuri, perilaku berbohong, dan aspek keadilan (kesamaan hak dan kewajiban) melalui cerita tentang hukuman dan otoritas.

\section{Penskoran dan Penafsiran Data}

Pada skoring setiap alternatif jawaban yang diberikan peserta didik diberi skor 1 jika memilih respon yang menggambarkan tahap penalaran moral heteronom, peserta didik diberi skor 2 jika memilih respon yang menggambarkan tahap penalaran moral semi otonom, dan peserta didik yang diberikan nilai 3 jika memilih respon yang menggambarkan tahap penalaran moral otonom. Angka yang dideskripsikan adalah gambaran yang diberikan responden mengenai penalaran moral, yang meliputi tahap penalaran moral heteronom, semi otonom, dan otonom berdasarkan aspek kepatuhan, kebenaran dan keadilan.

\section{Prosedur Penelitian}

Prosedur atau langkah-langkah yang akan dilaksanakan dalam penelitian quasi-experiment terdiri dari tiga tahapan yaitu :

\section{Tahap Pendahuluan}

Pendahuluan pada penelitian ini dimulai dengan mengidentifikasi masalah penelitian dengan studi lapangan dan studi pustaka, kemudian merumuskan instrumen penelitian (perumusan definisi konseptual, oprasional variabel, kisi-kisi instrumen. Selanjutnya, dilakukan penimbangan kelayakan instrumen oleh pakar, uji keterbacaan oleh beberapa peserta didik yang bukan sampel, dan melakukan uji validitas, dan reliabilitas instrumen sehingga menghasilkan instrumen yang terstandar.

\section{Tahap Pelaksanaan}

Instrumen penalaran moral disebarkan pada populasi penelitian. Hal ini bertujuan untuk mengungkap kondisi awal mengenai profil penalaran moral peserta didik kelas VIII SMPN 2 Ciledug. Data instrumen yang terkumpul kemudian diolah dan dianalisis sehingga menghasilkan data profil penalaran moral secara umum, dari profil ini dapat dilihat ketercapaian dan tingkat penalaran moral peserta didik apakah tergolong tinggi (otonom), sedang (semi otonom), atau rendah (heteronom). Analisis lebih detail dilihat dari segi aspek dan indikator penalaran moral peserta didik, sehingga dapat dilihat urgensi dari aspek dan indikator mana yang tepat sesuai kebutuhan untuk dilakukan intervensi. 


\section{Tahap Pelaporan}

Pada tahap pelaporan data yang diperoleh kemudian dianalisa dan diolah sebagai hasil penelitian, analisis data dilakukan atas dasar hasil penelitian berupa data kuantitatif. Pelaporan data kuantitatif melalui hasil pengolahan data dipaparkan pada hasil penelitian dan kesimpulan.

\section{HASIL DAN PEMBAHASAN}

\section{Profil Penalaran Moral Peserta Didik}

Berikut diuraikan profil peserta didik kelas VIII di SMPN 2 Ciledug Tahun Ajaran 2016/2017, baik secara umum maupun secara khusus berdasarkan aspek penalaran moral.

\section{Profil Penalaran Moral Peserta Didik}

Untuk menjawab pertanyaan penelitian mengenai profil penalaran moral peserta didik, peneliti melakukan survey menggunakan instrumen penalaran moral berbentuk cerita dilema berjumlah 20 item yang disebarkan kepada 230 siswa kelas VIII SMPN 2 Ciledug. Menghasilkan data penalaran moral peserta didik yang dijabarkan secara umum dan khusus berdasarkan aspek dan indikator penalaran moral. Secara umum profil penalaran moral peserta didik kelas VIII di SMPN 2 Ciledug 71\% berada pada kategori tahapan moral otonom (tinggi), dan $29 \%$ berada pada kategori semi otonom (sedang). Berikut profil penalaran moral pesrta didik SMP disajikan pada Grafik 1 di bawah ini.

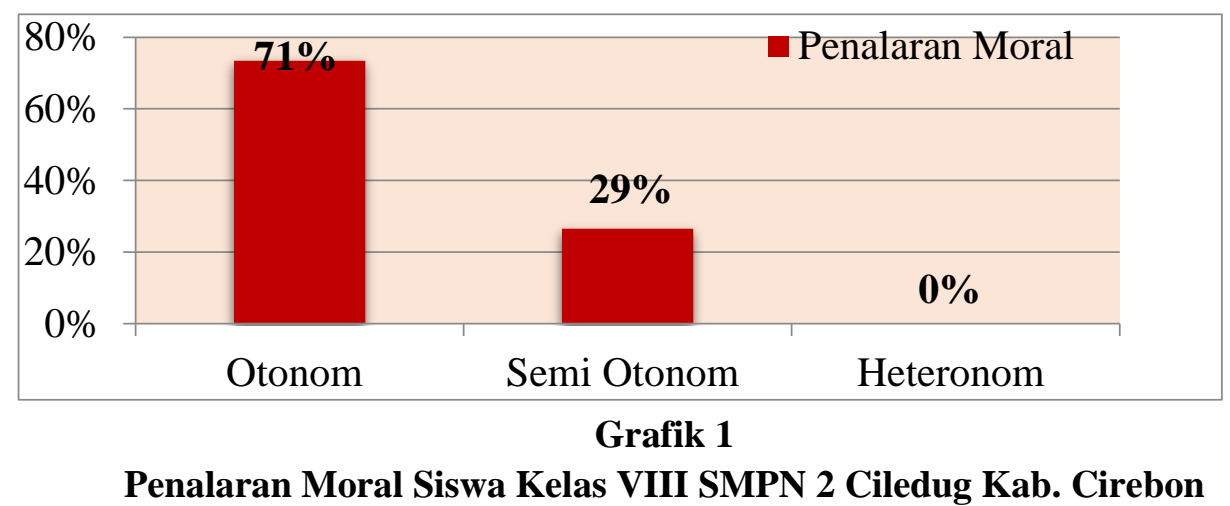

Grafik1 menggambarkan bahwa tingkat penalaran moral peserta didik kelas VIII SMP Negeri 2 Ciledug, Kab. Cirebon secara umum berada pada tahapan otonom (tinggi) dengan presentase $71 \%$, dan terdapat $29 \%$ yang masuk dalam tahapan semi otonom (sedang). Dari hasil ini menunjukan bahwa masih terdapat preserta didik yang tergolong pada tahapan semi otonom. Hal ini menggambarkan peserta didik belum sepenuhnya atau masih ragu dalam menempatkan diri pada posisi orang lain, belum sepenuhnya mempertimbangkan berbagai alasan dalam mengambil keputusan moral, belum sepenuhnya menyadari bahwa aturan dibuat oleh orang lain dan bisa disesuaikan, dan memilih atau mempertimbangkan hukuman yang dapat menggantikan kerugian korban dan membuat pelaku menyadari kesalahannya dan merubah perilakunya. 


\section{Profil Penalaran Moral Peserta Didik berdasarkan Aspek}

Setelah dipaparkan profil penalaran moral peserta didik kelas VIII di SMPN 2 Ciledug secara umum, pada paparan berikutnya disampaikan profil penalaran moral berdasarkan aspek yang meliputi aspek kepatuhan, aspek kebenaran dan aspek keadilan. Secara lebih rinci diuraikan pada Grafik 2 berikut.

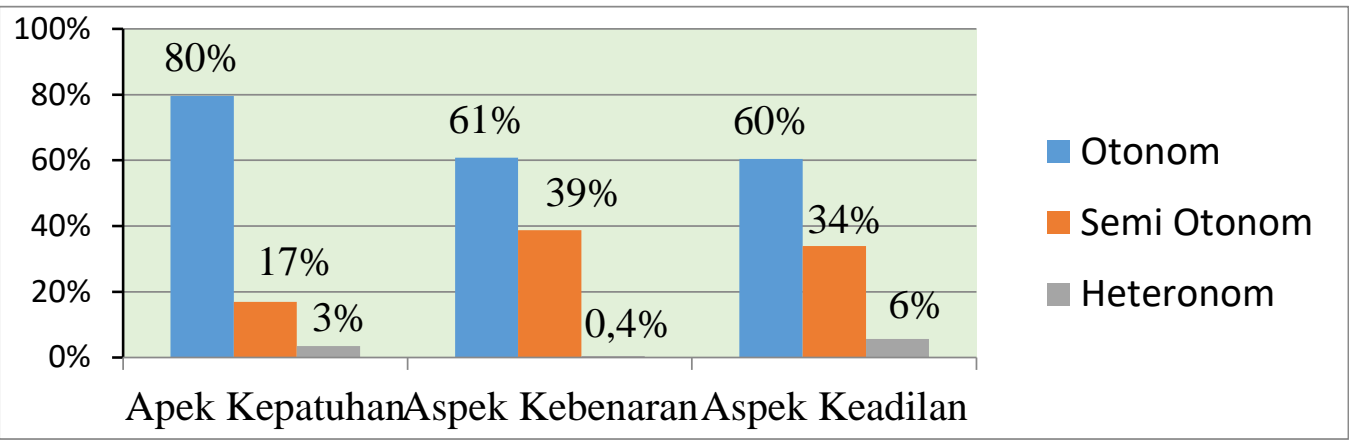

\section{Grafik 2}

\section{Profil Tingkat Pencapaian Penalaran Moral Peserta Didik Kelas VIII SMP Negeri 2 Ciledug Berdasarkan Aspek}

Pada aspek kepatuhan dengan deskripsi kesadaran akan peraturan dan pelaksanaan peraturan, meliputi cerita dilema moral tentang tindakan sembrono, memiliki presentase sebesar $80 \%$ atau 183 peserta didik berada pada tahapan otonom, $17 \%$ atau 39 peserta didik berada pada tahapan semi otonom dan $3 \%$ atau 8 peserta didik berada pada tahapan heteronom. Artinya, secara umum penalaran moral peserta didik dalam aspek kepatuhan berada pada kategori baik (otonom), kepatuhan terhadap suatu peraturan timbul karena peserta didik sudah memahami bahwa peraturan sebagai keputusan bebas yang harus dihormati karena disepakati bersama, namun masih terdapat $17 \%$ dan 3\% dari jumlah peserta didik berada pada tahap semi otonom dan heteronom, dengan karateristik peserta didik masih menganggap peraturan hanya berfungsi untuk mengatur suatu aktivitas, dan bersifat suci dan tidak bisa dirubah.

Aspek kebenaran dengan deskripsi pertimbangan benar dan salah, meliputi cerita dilema moral tentang tindakan mencuri dan berbohong, sebesar $61 \%$ atau 140 peserta didik berada pada tahapan otonom, $39 \%$ atau 89 peserta didik berada pada tahapan semi otonom, dan $0,4 \%$ atau 1 berada pada tahapan heteronom. Artinya, secara umum penalaran moral peserta didik pada aspek kebenaran/kejujuran berada pada kategori baik. Peserta didik sudah memahami bahwa kebenaran adalah apa yang sesuai dengan kenyataan, namun masih terdapat 39\% dan 0,4\% dari jumlah peserta didik berada pada tahap semi otonom dan heteronom, artinya peserta didik masih suka membesar-besarkan sesuatu yang bukan fakta (berbohong) dan peserta didik hanya menganggap kebenaran atau kejujuran sebagai sesuatu yang dapat menjaga kepercayaan orang lain. 
Aspek keadilan dengan deskripsi kesamaan hak dan kewajiban meliputi cerita dilema moral tentang hukuman dan otoritas sebesar $60 \%$ atau 139 peserta didik berada pada tahapan otonom, 34\% atau 78 peserta didik berada pada tahapan semi otonom, dan 6\% atau 13 peserta didik berada pada tahapan heteronom. Artinya, secara umum penalaran moral peserta didik pada aspek keadilan berada pada tahap otonom, peserta didik sudah melakukan tindakan atas dasar keseimbangan hak dan kewajiban. Namun masih terdapat $34 \%$ dan $6 \%$ dari jumlah peserta didik, masih berada pada tahap semi otonom dan heteronom, ini menggambarkan peserta didik masih melakukan tindakan atas permintaan dan perintah orang dewasa, serta belum terlalu memperhatikan tindakan yang seimbang atau mempunyai kesamaan antara kesamaan hak dan kewajiban.

\section{Profil Penalaran Moral Peserta Didik Berdasarkan Indikator}

Setelah dipaparkan profil penalaran moral berasarkan aspek, paparan selanjutnya disampaikan profil penalaran moral berdasarkan indikator. Berikut secara lebih rinci diuraikan pada Grafik 3.

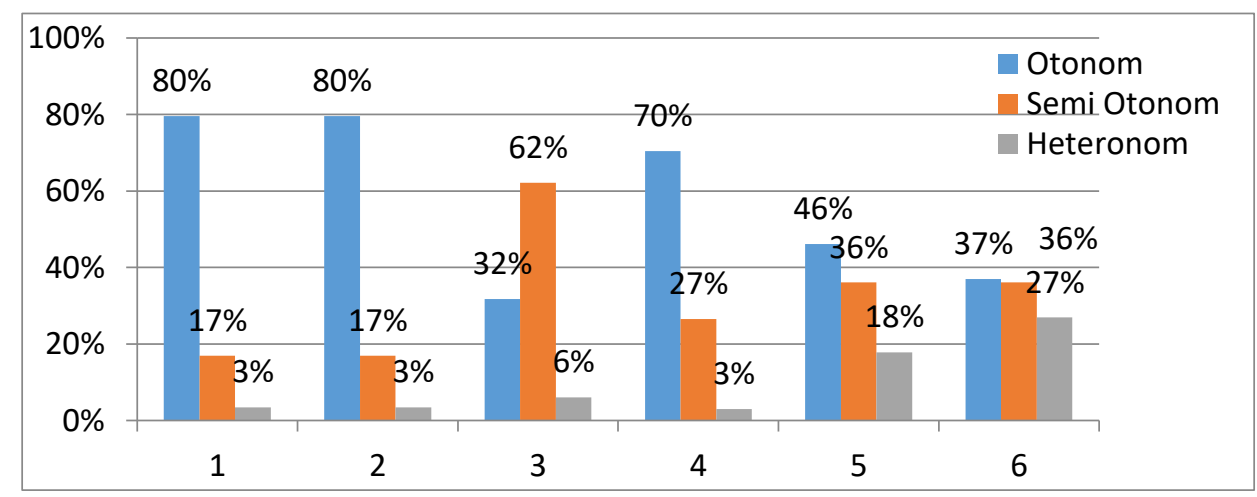

\section{Grafik 3}

\section{Profil penalaran Moral Peserta Didik SMPN 2 Ciledug Berdasarkan Indikator}

Grafik 3 mengungkapkan hasil profil penalaran moral berdasarkan indikator yang diantaranya pada indikator mengetahui peraturan sebagai keputusan yang bebas tidak bersifat kaku dan dapat disesuaikan, 3\% berada pada tahap heteronom, 17\% berada pada tahap semi otonom, dan $80 \%$ berada pada tahap otonom. Indikator menghormati peratuan yang telah disepakati bersama, $3 \%$ berada pada tahap heteronom, $17 \%$ berada pada tahap semi otonom, dan $80 \%$ berada pada tahap otonom. Indikator mengatakan sesuatu yang benar, $6 \%$ berada pada tahap heteronom, 62\% berada pada tahap semi otonom, 32\% berada pada tahap otonom. Indikator melihat intensi ketika membuat keputsan benar dan salah, 3\% berada pada tahap heteronom, 27\% berada pada tahap semi otonom, 70\% berada pada tahap otonom. 
Pada indikator menyetujui hukuman yang dirasa dapat membuat pelaku menyadari kesalahannya dan merubah perilakunya, $18 \%$ berada pada tahap heteronom, $36 \%$ berada pada tahap semi otonom, dan $46 \%$ berada pada tahap otonom. Dan pada indikator melakukan tindakan atas dasar kesamaan hak dan kewajiban, sebesar $27 \%$ berada pada tahap heteronom, 36\% berada pada tahap semi otonom, 37\% berada pada tahap otonom.

Berdasarkan hasil temuan penelitian, menunjukann bahwa profil penalaran moral peserta didik kelas VIII SMP Negeri 2 Ciledug, Kab. Cirebon Tahun Ajaran 2016/2017 secara umum sudah berada pada tahapan otonom (tinggi) dengan karateristik peserta didik telah mampu menempatkan diri pada posisi orang lain, mampu mempertimbangkan berbagai alasan dalam mengambil sebuah keputusan moral, menyadari bahwa aturan dibuat oleh orang lain dan bisa disesuaikan, menyukai dan memilih hukuman yang dapat menggantikan kerugian korban dan membuat pelaku menyadari kesalahannya dan merubah perilakunya. Namun, masih terdapat peserta didik kelas VIII yang masih berada pada tahapan penalaran moral semi otonom (sedang), yang menggambarkan bahwa peserta didik masih belum sepenuhnya atau masih ragu dalam menempatkan diri pada posisi orang lain, belum sepenuhnya mempertimbangkan berbagai alasan dalam mengambil keputusan moral, belum sepenuhnya menyadari bahwa aturan dibuat oleh orang lain dan bisa disesuaikan, dan memilih atau mempertimbangkan hukuman yang dapat menggantikan kerugian korban dan membuat pelaku menyadari kesalahannya dan merubah perilakunya.

Hal penelitian menunjukan, meskipun secara umum penalaran moral peserta didik sudah berada pada tahap otonom, namun masih terdapat preserta didik berada pada tahap semi otonom dan belum mencapai tahap penalaran moral yang ideal yaitu penalaran moral otonom. Piaget (dalam Duska dan Whelan, 1982, hlm. 31) perkembangan penalaran moral otonom seharusnya telah dicapai selama masa remaja. Mengingat perkembangan penalaran moral berkembang sejalan dengan tahapan-tahapan perkembangan kognitif (Piaget ; Slavin, 2011, hlm. 67).

Peserta didik SMP sebagai remaja menurut Piaget (dalam Hurlock, 1980, hlm. 225) telah mencapai tahap perkembangan kognitif operasional formal, yaitu tahap dimana remaja telah mampu mempertimbangkan semua kemungkinan untuk menyelesaikan suatu permasalahan dan mempertanggungjawabkannya berdasarkan suatu hipotesis atau proposisi. Artinya remaja sudah dapat memandang masalahmasalahnya dari berbagai sudut pandang dan menyelesaikannya dengan mengambil banyak faktor sebagai dasar pertimbangan, bernalar secara lebih abstrak, idealis dan logis.

Peserta didik kelas VIII SMPN 2 Ciledug terbagi ke dalam tujuh kelas, namun tingkat pencapaian penalaran pada setiap kelas secara umum berada pada tahapan otonom, hanya terdapat dua kelas yang memiliki skor rata-rata penalaran moral masuk dalam tahapan semi otonom. Secara teoritis sebagaian para remaja belum mencapai penalaran moral yang otonom. Hal tersebut menurut Colby dan Kohlberg (Kurtines \& Gerwitz, 1992, hlm. 78-79) perubahan yang berkaitan dengan perkembangan selama 
kurun waktu tertentu akan mencangkup peningkatan yang cukup menentukan pada tahap penalaran berikutnya, namun disertai juga penurunan dalam penggunaan pola penalaran pada tahapan sebelumnya yang lebih rendah, hal tersebut berarti bahwa seseorang itu paling sering berada dalam peralihan di antara dua tahapan yang berdekatan, yakni tidak lagi menggunakan pola penalaran dari tahapan yang lebih rendah namun juga tidak menggunakan pola penalaran yang lebih tinggi.

Hal di atas, didukung hasil temuan penelitian Colby dan Kohlberg (Kurtines \& Gerwitz, 1992, hlm. 75) anak berusia remaja dini (13-14) tahun menunjukan skor bahwa sebagian besar anak berada pada tahap 2 (orientasi relativis instrumental) dan tahap 3 (orientasi kesepakatan antar pribadi) dan sebagian lagi berada pada tahap 3 dan 4. Secara umum hasil penelitian ini sebagian besar usia remja awal berada pada tahapan peralihan, dalam penelitian ini disebut sebagai tahap semi otonom.

Faktor lain yang mungkin menjadi pengaruh adalah faktor peserta didik yang pasif dalam berinteraksi dengan sosialnya. Khususnya ketika individu beralih dari lingkungan yang relatif homogen ke lingkungan yang lebih heterogen. Martin Hofman (dalam Santrock, 2007, hlm 303) mengungkapkan bahwa di lingkungan heterogen individu dihadapkan pada berbagai kontradiksi antara konsep-konsep moral yang telah diterima dan dialami di luar keluarganya dan lingkungan rumahnya. Dititik ini remaja mulai mengenali serangkaian keyakinannya sekaligus menyadari bahwa keyakinan mereka itu hanyalah salah satu di antara berbagai keyakinan orang-orang lainakan mempengaruhi kemampuan penalaran moralnya. Senada dengan itu, Eisenberg, Zhou, \& Koller, (2001) mengungkapkan bahwa kemampuan penalaran moral berkembang seiring bertambahnya usia, seiring remaja meningkatkan interaksi sosial, mampu berempati dan pengambilan peran.

Perkembangan penalaran moral menurut Piaget (Nucci dan Narvaez, 2014, hlm, 514) terkait dengan pergeseran secara bertahap dari moralitas heteronom kepada moralitas otonom. Dengan kata lain perkembangan tahap penalaran moral bergeser secara bertahap dari tahap heteronom (rendah) menuju kepada tahap penalaran moral otonom (tinggi). Piaget (Duska dan Whelan, 1982, hlm. 54) mengemukakan bahwa pencapaian penalaran moral ke tahap otonom berlangsung seumur hidup dan dimulai sejak usia 12 tahun, ditunjukkan oleh adanya pembebasan dari heteronom dengan cara memikirkan peraturan-peraturan moral (seperti memikirkan hal-hal lain), membuat generalisasi, mengaitkan peraturan-peraturan moral itu satu sama lain, kemudian memperluas peraturan-peraturan moral itu secara progresif, hingga tercapai universalitas.

Peserta didik yang berada pada tahap penalaran otonom, menunjukkan bahwa sudah lepas dari kekangan tahap penalaran moral heteronom, karena dilihat dari segi kognitif dan sosial remja sudah mulai matang, sehingga peserta didik mampu melihat tindakan dari perspektif lain yang berbeda dengan perspektifnya sendiri dan mampu mengadakan pertimbangan berdasarkan tanggung jawabnya sendiri. Kekangan 
heteronom di sini adalah kekangan karena adanya rasa wajib mematuhi peraturan dan rasa hormat unilateral, yaitu rasa hormat terhadap peraturan dan otoritas orang dewasa.

Penalaran moral terdiri dari tiga aspek yaitu aspek kepatuhan, kebenaran dan keadilan. Adapun hasil pencapaian setiap aspek sebagai berikut : pada aspek kepatuhan meliputi indikator mengetahui peraturan sebagai keputusan yang bebas tidak bersifat kaku dapat disesuaikan, menghormati peratuan yang telah disepakati bersama berdasarkan cerita dilema perilaku sembrono dengan pencapaian presentase sebesar $85,4 \%$. Aspek kebenaran meliputi indikator mengatakan sesuatu yang benar, melihat intensi ketika membuat keputsan benar dan salah berdasarkan cerita dilema tindakan mencuri dan berbohong dengan pencapaian presentase sebesar 78,4\% Aspek keadilan meliputi indikator individu melakukan tindakan atas dasar kesamaan hak dan kewajiban, menyetujui hukuman yang dirasa dapat membuat pelaku menyadari kesalahannya dan merubah perilakunya berdasarkan cerita dilema hukuman dan otoritas dengan pencapaian sebesar $80,3 \%$. Dari data tersebut dapat dilihat aspek kebenaran merupakan aspek terendah dan aspek kepatuhan pada pencapaian tertinggi. Hal ini bisa saja terjadi, didukung oleh pernyataan Piaget (Duska dan Whelan, 1982) bahwa pada aspek kebenaran/kejujuran dengan cerita dilema perilaku mencuri dan berbohong merupakan persoalan yang komplek dan serius. Kebohongan merupakan kecenderungan bawaan bagi anak-anak terutama jika berada pada tahap heteronom, maka akan melekat pada cara berpikir egosentris, Piaget menambahkan realism moral pada anak mengenai kebohongan berlangsung lebih lama dari pada realisme perbuatan keliru, mencuri karena alasan yang bermacam-macam.

\section{SIMPULAN}

Profil penalaran moral peserta didik kelas VIII SMPN 2 Ciledug secara umum berada pada kategori tahapan otonom (tinggi), namun terdapat sebagian berada pada tahapan semi otonom (sedang) dilihat dari aspek dan indikatornya. Ini menunjukkan bahwa masih terdapat preserta didik yang belum mencapai tahap penalaran moral yang ideal. Peserta didik dengan penalaran moral semi otonom (sedang) menggambarkan bahwa peserta didik belum sepenuhnya atau masih ragu dalam menempatkan diri pada posisi orang lain, belum sepenuhnya mempertimbangkan berbagai alasan dalam mengambil keputusan moral, belum sepenuhnya menyadari bahwa aturan dibuat oleh orang lain dan bisa disesuaikan, dan memilih atau mempertimbangkan hukuman yang dapat menggantikan kerugian korban dan membuat pelaku menyadari kesalahannya dan merubah perilakunya.

\section{DAFTAR PUSTAKA}

Abdolmohammadi, M.J \& Baker, C.R. (2006). Accountants' Value Preferences and Moral Reasoning. Journal of Business Ethnic, 69, hlm. 11-25.

Abdolmohammadi, M., Sultan, J., \& Ethics, B. (2002). Ethical Reasoning and the Use of Insider in Stock Trading Information. Journal of Business Ethics, 37(2), 165-173. 
Astuti, F.H. (2014). Pengembangan Paduan Pelatihan Moral Awareness untuk Siswa SMP. Jurnal Paedagogy. 1(1), hlm. 1-13.

Barger, B \& Pitt, D. W. (2013). Do Negative Mood States Impact Moral Reasoning?. Journal of Moral Education, 42(4), hlm. 443-359.

Bartels, D. M.,dkk. (2015). “Moral Judgment and Decision Making,” In G. Keren \& G. Wu (Eds.) The Wiley Blackwell Handbook of Judgment and Decision Making. Chichester, UK: Wiley.

Basyirudin, F. (2010). Hubungan Antara Penalaran Moral Dengan Perilaku Bullying Pada Santri Madrasah Aliah Pondok Pesantren Assa'adah Serang Banten. Skripsi. Publikasi web. Jakarta : UIN.

Beerthuizen, M. G., Brugman, D. \& Basinger, K.S. (2013). Oppositional Defiance, Moral Reasoning and Moral Value Evaluation as Predictors of Self-Reported Juvenile Delinquency. Journal of Moral Education, 42(4), hlm. 460-474.

Borba, M. (2008). Membangun Kecerdasan Moral Tujuh Kebijakan Utama Agar Anak Bermoral Tinggi. Jakarta : Gramedia Pustaka Utama

Cheppy. (1988). Pendidikan Moral dalam Beberapa Pendekatan. Jakarta: Departemen Pendidikan dan Kebudayaan Direktorat Pendidikan Tinggi. PPLPTK.

Creswell, J. W. (2010). Research Design, Edisi Ketiga: Pendekatan Kualitatif, Kuantitatif, dan Mixed (Diterjemahkan oleh Ahmad Fawaid). Yogyakarta: Pustaka Pelajar.

Duska, R. \& Whelan, M. (1982). Perkembangan Moral. Perkenalan dengan Piaget dan Kohlberg. Penerjemah : Dwija Atmaka. Yogyakarta : Yayasan Kanisius.

Flaherty, J.O \& Gleeson J. (2014). Longitudinal study of levels of moral reasoning of undergraduate students in an Irish university: the influence of contextual factors. Journal Educational Studies Association of Ireland. Irish Educational Studies. 33(1), hlm. 57-74.

Gordon, E. W., \& Heincke, P. (2013). To assess, to teach, to learn: A vision for the future of assessment : technical report. Retrieved from Gordon Commission on the Future of Assessment in Education (U.S.) : http://www.gordoncommission.org

Horstink, Tim. (2012). The Effects of Social Networks on Group Moral Reasoning in the Royal Netherlands Army. Article publication. Communication studies, Universiteit Twente.

Hurlock, E. B. (2011). Psikologi Perkembangan Edisi Kelima. Jakarta: Erlangga.

Ibung, D. (2009). Mengembangkan nilai moral pada anak. Jakarta: Gramedia. 
Ilham W. T. (2012). Hubungan Antara Tingkat Penalaran Moral Dengan Kedisiplinan Siswa SMKN I Sragen. Naskah publikasi Skripsi. Universitas Muhammadiyah Surakarta.

Joanne, F. (2014). Making the Case for Moral Development Education. Journal of Further and Higher Education, 38(2), hlm. 147-162.

Kurtines, M. W \& Gerwitz, J. L. (1992). Morality, Moral Behavior \& Moral Development. (Alih bahasa M.I. Soelaeman). Jakarta : Universitas Indonesia Press.

Lewis, J \& Young, S. J. (2000) The Relationship of Moral Reasoning Style to Counselor Expression of Empathy. The Journal of College Counseling, 3(2), hlm. 113-122.

Muryono, S. (2009). Empati, Penalaran Moral dan Pola Asus Telaah Bimbingan dan Konseling. Yogyakarta : Gala Ilmu Semesta.

Nucci, L \& Narvaez, D. (2014). Handbook Pendidikan Moral dan Karakter. Terjmahan. Bandung : Nusa Media.

Perren, S, dkk. (2012). Moral reasoning and emotion attributions of adolescent bullies, victims, and bully-victims. Zuerst ersch. in : British Journal of Developmental Psychology. 30 (4), hlm. 511-530.

Ponemon, L. A., \& College, B. (1992). Auditor underreporting of time and moral reasoning : An experimental lab study. Contemporary Accounting Research, 9(1), hlm. 171-189.

Purwanti, E, L. \& Muhari. (2013). Hubungan antara Tingkat Penalaran Moral pada Remaja dengan Perilaku Seks Pranikah di kost “Ad”. Journal Psikologi UNESA. Character, $1(2)$.

Rose, J. D. (2012). Development of Moral Reasoning at a Higher Education Institution in Nigeria. Emerging Leadership Journeys, Journal Regent University School of Global Leadership \& Entrepreneurship. 5(1), 81- 101.

Sadler, T. D., \& Zeidler, D. L. (2005). Patterns Of Informal Reasoning In The Context Of Socioscientific Decision Making. Journal of Research in Science Teaching, 42(1), $112-138$.

Santrock, J.W. (2003). Perkembangan Remaja. Alih Bahasa oleh: Shinto B. Adelar dan Sherly Saragih. Jakarta: Erlangga.

Santrock, J.W. (2007). Adolescene, eleventh edition, Remaja. Edisi kesebelas. Terjemahan. Jakarta : Erlangga.

Slavin, R. E. (2011). Educational Psychology: Theory and Practice, 9th ed. (Terjemahan). Jakarta : Indeks. 
Uddin, N. \& Gillett, P. R. (2002). The Effects of Moral and Self-Monitoring Intentions to Report on Financial Statements Reasoning on CFO Fraudulently. Journal of Business Ethics, 40(1), 15-32.

Xu, Y. \& Ziegenfuss, D. E. (2008). Reward Systems, Moral Reasoning, and Internal Auditors' Reporting Wrongdoing. Journal of Business and Psychology, 22(4), 323331. 
242 | Laras - Profil Penalaran Moral ... 